Bojan Žalec

\title{
Between Secularity and Post-Secularity: Critical Appraisal of Charles Taylor's Account ${ }^{1}$
}

\section{Med sekularnostjo in postsekularnostjo: kritična ocena pojasnitve Charlesa Taylorja}

Abstract: The article deals with Charles Taylor's account of the secular age. In the first part, the main constituents of Taylor's narrative account are presented: the central concepts, distinctions, definition of the subject, the aims etc. The author pays special attention to the notions of secularity, secular age, religion, and transcendence. In the second part, Taylor's genealogy of the secular age is outlined and comparatively placed in the context of other main relative forms of genealogical account. Because our age is an age of authenticity, a special section is devoted to it. The final section presents some reproaches to Taylor and evaluates their strength and the value of Taylor's contribution. Besides, some speculative "forecasts" about secularity and post-secularity in Europe, the USA, and at the global scale are presented (by reference to Taylor's account). The author concludes that despite some (serious and cogent) reproaches and second thoughts about Taylor's account, it is doubtless one of the major achievements in the area that manifests features of a paradigmatic work. It helps us a lot to understand the condition of religion not only in the past and today, but also gives us directions and guidelines, conceptual and methodological tools, and ideas to more clearly discern the forms and condition of religion in the future.

Key words: Charles Taylor, secularization, secular age, religion, transcendence, genealogy, authenticity, post-secularity.

Povz̨etek: Članek se ukvarja s pojasnitvijo sekularne dobe, ki jo zasledimo v delu Charlesa Taylorja. V prvem delu so predstavljeni glavni elementi Taylorjeve narativne pojasnitve: središčni pojmi, razlikovanja, opredelitev predmeta, nameni itd. Avtor posveti posebno pozornost pojmom sekularnosti, sekularne dobe,

1 This paper is a result of the The Research Programme Ethical-religious Grounds and Perspectives of the Society and the Religious Studies in Context of Education and Violence (P6-0269) and basic research projects The Return of the Religious in Postmodern Thought as a Challenge for Theology (J6-7325), Reanimating Cosmic Justice: Poetics of the Feminine (J6-8265) and Interreligious Dialogue - a Basis for Coexisting Diversity in the Light of Migration and the Refugee Crisis (J6-9393), which are financed by the Slovenian Research Agency. 
religije in presežnosti. $V$ drugem delu oriše Taylorjevo genealogijo sekularne dobe, ki jo primerjalno umesti v kontekst drugih glavnih relevantnih oblik genealoške pojasnitve. Ker je naša doba doba pristnosti, ji avtor posveti poseben razdelek. Zadnji razdelek predstavi nekatere kritike Taylorja, ovrednoti njihovo težo, pa tudi vrednost Taylorjevega prispevka. Poleg tega so podane - v nanašanju na Taylorjevo pojasnitev - spekulativne »napovedi« o sekularnosti in post-sekularnosti v Evropi, ZDA in na globalni ravni. Avtor zaključi, da je Taylorjeva pojasnitev, kljub nekaterim (resnim in tehtnim) očitkom ter pomislekom, nedvomno izjemen dosežek. Izkazuje značilnosti paradigmatičnega dela. Ne samo da nam zelo pomaga razumeti položaj religije $v$ preteklosti in danes, ampak nam daje tudi usmeritve in smernice, pojmovna in metodološka orodja ter ideje za jasnejše razbiranje oblik in položaja religije v prihodnosti.

Ključne besede: Charles Taylor, sekularizacija, sekularna doba, religija, presežnost, genealogija, pristnost, postsekularnost

In this paper, I will present ${ }^{2}$ Charles Taylor's understanding of (our) secular age and its genesis. Taylor's aim is an analysis and understanding of the conditions, characteristics and potentials of religious belief today. His starting premise is that the conditions of belief determine the nature of belief: if the relevant conditions of two beliefs are different then also these beliefs are different. So, for instance many people nowadays say: "Today people don't believe but in the past, they believed «. However, this comparison is only conditional because the conditions of belief changed (Hoffmann 2017, 272). Taylor stresses that his narrative covers only West, ${ }^{3}$ i.e. North Western Europe, the USA and Canada. Despite these constraints, I think that it is enlightening and useful also for understanding in a broader frame.

\section{Secularisation and a Secular Age}

Taylor discerns three meanings of "secularization «: In the first sense (S1), secularization is understood in terms of public space - which concerns common institutions and practices. Societal subsystems (economy, politics, religion, legal sphere, education, science ...) have become differentiated, separated and autonomous. But Taylor points out that the fact that religion is not present any more in the autonomous public areas doesn't mean that people don't believe any more. Maybe the example is even Poland under communism, but certainly the USA. The USA is

2 Beside Taylor 2007, his most important works relevant for our paper are Taylor 1989 and 1991. From the secondary sources, we should mention the condensed presentations and valuable reflections on Taylor's (relevant) views and approaches in Abbey 2000 and 2017, Smith 2014, and Hoffmann 2017.

3 Taylor speaks about »our (North Atlantic, or sWestern`) civilization« (Taylor 2007, 15) or about »changes which have arisen in one particular civilization, that of the modern West - or in an earlier incarnation, Latin Christendom«. 
one of the first secularised countries in this first sense. But statistically (religious belief and praxis), it is one of the most religious. For this reason, Taylor alleges the second meaning of secularization (S2), which consists in people not visiting church any more. In this sense, the majority of Western countries have become secular. But Taylor notes: "Deconfessionalization is a major phenomenon, but it by no means betokens simply unbelief. Religion does not decline because churches do" (Taylor 1990, 105). So, both two meanings of "secularization « mentioned above are insufficient for a complete and adequate description of our condition today (Abbey 2000, 196). Moreover, they don't encompass the most important characteristic of present condition, which is the key to its true understanding. Therefore, Taylor introduces the third meaning of secularity (S3) which focuses on the background of belief. The shift in secularity consists in that that in the secular societies a belief in God has been set under the question and challenged. In this sense the main environments in the USA are secularized and probably the USA in general. The opposite examples are the majority of Muslim countries and the environments where the majority of people in India live (Taylor 2007, 1-3).

Secularity in this third sense is the true subject of Taylor's interest; and it is the age which is secular in this third sense that is the subject of his seminal work from 2007. S3 is a matter of the integral context of understanding in which our modern, spiritual and religious experience takes place. With this "context " Taylor means not only the things to which almost everybody would explicitly point - as for instance a plurality of options - but also the elements which are a part of the implicit, »hidden « part of this context. This is the background of our experience and (spiritual) searching to which mostly we don't pay attention. Taylor speaks - in a Heideggerian manner - about the "pre-ontology « of this searching (3). Whether a society is secular or not in the third sense (S3) depends on the conditions under which their members' experience and (spiritual) searching take place.

According to Taylor, the difference between secular and religious view consists in where they put the origin of fullness of human life (10-11). The same point he expresses also by saying that today we can live a spiritual life in different ways, that the strength and fullness of life can take different forms, and the »exiles" as well (11). Because of the changed condition of belief, «belief in God isn't quite the same thing in 1500 and 2000 « (13). These conditions philosophers - influenced by Heidegger, Wittgenstein, and Polany - call »background «. ${ }^{4}$ People cultivate all their beliefs inside the frame which usually remains tacitly assumed, but the subject or the agent of belief may not acknowledge it because this frame is never explicitly formulated. Thus, what Taylor has here in mind are not some changes of belief at the propositional or discursive level ("decline« of hell, new understanding of atonement etc.), therefore the changes through which even orthodox Christianity has gone. No, even in the case of the identical propositions of belief, a belief now (in the secular age) and before are - because of the changed background - different. Taylor speaks about the disruption of the earlier background.

4 For the importance of backgrounds, see Žalec 2016. 
These changes become most visible if we focus on some distinctions - for instance between immanent and transcendent, natural and super-natural etc. - which today practically everybody understands, regardless if they accept them or refuse the second term of the pairs (13-14). Therefore, S3 refers to the change or shift in the background of belief: "/t is this shift in background, in the whole context in which we experience and search of fullness, that I am calling the coming of secular age, in my third sense (14). And he immediately adds:

"How did we move from a condition where, in Christendom, people lived naïvely within theistic construal, to one in which we all shunt between two stances, in which everyoness construal shows up as such: and in which moreover, unbelief has become for many the major default option? This is the transformation that I want to describe, and perhaps (alas very partially) explain in the following chapters" (14). ${ }^{5}$

This task is in no way an easy one, but only through identifying changes as changes of lived experience, we can start rising the right questions properly, and we avoid naïve views and accounts on all sides as are the following: non-belief is only a fall away of every sense of fullness or it's betrayal (what theists sometimes are tempted to think about the atheists); a belief is only a set of theories which try to make sense of experiences which we all have and which nature can be understood totally immanently (what atheists are sometimes tempted to think about theists). But in fact, we must, as Taylor stresses, understand the differences between these options not only in terms of creeds, but also in terms of differences in experiences and sensibility. What happened is a massive change in the whole background of belief and unbelief, which consists in disappearance of the "naïve» frame and establishing of the »reflective one«. We must bear in mind that after this change, both believers and non-believers experience their worlds very differently (14).

The characteristic of the secular age is that it happened first time in human history that self-sufficient humanism became a viable option. Self-sufficient humanism - or exclusive humanism, these are synonyms for Taylor - is a standpoint which doesn't accept any final ends beyond human flourishing and no commitment to anything beyond this flourishing. This is not true about any previous societies (18). Taylor notes that humanism has appeared already before, but it was not self-sufficient or exclusive. ${ }^{6}$ Further, he accepts that there were also exclusive humanisms before the secular age, for instance Epicureanism in Antiquity. But only in the secular age exclusive humanism became widely spread and accessible option. In the past this was true only about some small elite which itself was a minority (19). It is important that we bear in mind that modern secularity (S3) is neither identical nor equivalent with exclusive humanism. S3 (hereafter simply secularity) is a condition in which experience and searching for fullness of both

5 We may maybe say that our faith before was naïve realism, now it can be at most critical realism.

6 About the temporal frame of the development of exclusive humanism, see also Abbey 2000, 200. 
believers and non-believers take place. Further, exclusive humanism is not the only alternative to religion. In our age there are intellectual currents which we can call non-religious anti-humanism which according to Taylor today appear under several names as for instance »deconstruction « and »post-structuralism « and which are rooted in some very influential texts of $19^{\text {th }}$ Century, especially in Nietzsche. Taylor mentions here also deep ecology, which tries to find non-exclusive humanism on a non-religious basis. This deep ecology takes different forms.

We can summarise what we said above as follows: the secular age finished the period of naïve religious belief. Its deciding characteristic is coming of exclusive humanism on a sociologically relevant scale. For the first time in history "the eclipse of all goals beyond human flourishing becomes conceivable; or better, it falls within the range of an imaginable life for masses of people« (20).

\section{Religion and Dimensions of Transcendence}

Taylor defines religion by the concept of transcendence: religion offers a transformation which goes beyond human perfection. He discerns three dimensions of transcendence, and religion combines all three. ${ }^{7}$ We can explain these three dimensions by the example of Christianity. In it, we can find: 1 . Good (of man) which transcends mere human prosperity. This is agape, love, that God has for us and in which we can partake through his love. Thus, it is offered to us a possibility of transformation which leads beyond merely human perfection. We can become super-natural, more as merely human(s); 2. A higher, transcendent power (God) which reaches beyond human perfection and is understandable to us - makes sense - only in the context of belief in a higher, transcendent God of faith, who appears in the majorities of the definitions of belief; 3. Posthumous life, a life beyond this life. Our story about the potential transformation through agape demands that we see our lives as extending beyond their "natural « scope between birth and death, in other words, beyond «this life". In short, according to Taylor (Christian) transcendence and religion have three dimensions: a good which surpasses the mere human perfection, the power which makes possible human reaching of this perfection, and the belief that our life extends beyond this life (beyond our birth and death). In order to understand the struggle, rivalry, or debate between religion and unbelief in our culture, we must, Taylor says, understand religion as combining all these three dimensions of transcendence. In our culture, there are many options which are somewhere between the option which affirms these three dimensions, and their total denial, thus a total denial of religion. But the debate in our society, which otherwise includes different standpoints, is primarily shaped by two »extremes«: transcendent religion on one hand, and its frontal denial on the other. Taylor claims that this is a fact about the modern cul-

7 On the phenomenological understanding (Husserl, Heidegger, Levinas, Marion) of transcendence, self-transcendence, and temporality see Klun 2017. On the Biblical monotheism and its comprehension of transcendent God see Petkovšek 2017, 625. 
ture. But in general, the naïvety is not possible (any more) for nobody in the secular age. This situation includes different environments in which there may be different default options than in others although those who inhabit those environments are well aware of the default options preferred by others and they can't any more dismiss them as an unexplainable exotic error (21). In this sense Taylor speaks about the "mutual fragilization « of beliefs or "world views" in the secular age (303). Thus, S3 is not a term opposite to the term "religious" but it rather denotes the entire frame in which today all worldviews are situated. It is the result of the transformation of society from one in which not believing in God is impossible, into society in which belief in God is just one among other »worldviews « or beliefs. The secular age is according to Taylor irreversible (Taylor 1989, 401; Abbey 2000, 199): no return to pre-secular condition is possible. Earlier, the natural order, the societal order, the family, and the lives of individuals were explained with a reference to God. Belief in God has been a self-evident frame. In the secular age, after the change, nature, society, and lives of individuals, they are all explained without reference to God. One can still do it, but they don't have to because they can explain and interpret the world entirely from the immanent world itself. But in general, a belief, and other beliefs or non-beliefs are just one interpretation among others.

\section{Genealogy}

Taylor uses frequently some concepts, distinctions, periodisations, classifications etc., among them division of religions on pre-axial, axial and post-axial (Christianity and Islam), and his threefold periodisation of the Modern Age: the age of Ancien Regime, the age of mobilization (1800-1950), and the age of authenticity, from the 1960s onwards. Taylor's genealogy of the secular age is very complex and involves many factors. But among the drivers of secularization, Taylor stresses especially two that are mutually connected. The first is the Reform, the second is the development of science. But the most important is the first, the Reform. The Reform started in the $16^{\text {th }}$ century in North Western Europe. It originates in the coincidence of military, economic and religious interests. It includes the process of civilizing and disciplining of the European citizens, demythologization and disenchantment of the world (Taylor 2007, 61-88; 116-117; 216-217; 464-466; $496-499 ; 503-504 ; 613-615)$. The results were fundamental and crucial changes of the Western thought, culture and society, in the European theological, metaphysical, economical, moral, social and political segments. Among them, Taylor stresses as the most basic and important especially the following four: 1 . new understanding of a self as a buffered, nonporous entity (Abbey 2000, $203 \mathrm{ff}$ ); 2. disenchantment of the world (203ff); 3. naturalization of time (204ff); 4. new, modern societal imaginary (205ff): the idea of modern moral order and its penetration in the societal imaginary which it has transformed in a new one. The project of the Reform contributed to disembedding, i.e. it increased the distancing 
and even hostility toward older forms of belonging and rituals. This disembedding - which is a matter of both, of identity (the contextual limits of the image of self), and of the social imagination (about the whole society) - was characteristic for elites (156).

The main features of the (idea of) modern moral order can be summarized in four characteristics (Taylor 2007, 170-171): 1. The original idea of mutual benefits has passed over into the theory of rights and legitimate rule; 2 . Political society makes possible, as an instrument, for individuals to serve each other both in providing of security and in strengthening of exchange and prosperity as well; 3 . The starting point are individuals whom society must serve; 4 . These rights, liberty, and mutual benefit must be provided and secured equally for all citizens. What exactly is meant with »equality« changes, but the demand for enacting of some equality is evident already from the refusal of a hierarchical order. According to Taylor, these are the crucial characteristics and constants appearing in the modern idea of moral order, through all its changing "redactions" (171).

According to Casanova $(2010,267)$, there are four basic forms of genealogical account of modernity and secularism. The first is triumphant secularism. At this point we should mention a special stadial historical consciousness, a special secularist stadial conception of history. This secularist stadial consciousness is the outlook that sees exclusive humanism as the final and highest stadium in the progress of science and rationality (see also Strahovnik 2017, 270; 276 for the idea of secular fundamentalism that takes this form even further). According to Taylor, this stadial historical consciousness is a crucial part and pillar of the triumphalist secularist view. Besides, the stadial consciousness functions as a ratchet which makes the leaving behind of secularism impossible (Taylor 2007, 289). It would be a deep intellectual regression. But for the stadial consciousness such »[i]ntellectual regression would be unthinkable; it would involve pretending that we could go back « (289). We should add that also for Taylor the return from the secular age to the pre-secular is not possible. But of course, he thinks and hopes that the post-secular age is coming.

The second genealogical account is traditionalist - mostly Catholic - criticism of secularity as a deviation in intellectual and normative sense. The third is protestant account that sees secularity as internal to realization of true Christianity (at the institutional level). The fourth is a rejection of exclusive humanism in a Nietzschean way. Taylor accepts some particular insights of all four accounts, but he is far from really and integrally accepting any of them. He criticizes all of them for the unidirectional teleology and for one-sidedness. His own account is characterized by zig zag thinking and unintended shifts in understanding and accounting.

Taylor's main reproach to the first account is that it is blind for the role of Christianity as a root of secularity. Secularist triumphalism is blind for the particular contingent fact that Western secularism - its benevolence and universalism - is possible only as the (re)configuration of Christian agape. Taylor's reasons for refusing the second approach are on one side familiar moral reasons which are to- 
day well known and widely spread. These reasons are visible also from Taylor's approval and positive inclination to Kearney's anatheism (Kearney and Taylor 2016, $77 ; 84 ; 87 ; 90)$. But besides these reasons, he refuses the traditionalist approach also because of its incapability to see the internal connection between Christianity, and secularism and the secular age. The "traditionalist " Christianity would be today possible only as a (partial) "(self)mutilation « of Christianity.

The third account is problematic for Taylor because its representatives don't see the great losses we suffer with the establishing of the immanent frame. One of the main aims of the book A Secular Age is pointing out these loses. And lastly, Taylor can certainly partly sympathise and empathise with the Nietzschean criticism of exclusive humanism, for instance with its criticism of the rationalism of exclusive humanism. But he can sympathise also with exclusive humanism because exclusive humanism has taken many values from Christianity, but it pulled them out from the Christian religious and metaphysical context and put them in the immanentist horizon. On the other hand, he cannot fully support Nietzschean immanent anti-humanism because of its criticism of any metaphysical grounding of transcendence. In such a way immanent anti-humanism reinforces the very component of exclusive humanism that Taylor wants to destabilize.

In general, Taylor doesn't want to take part or side in the discussion between traditionalists and secularists which is in general interpreted as the debate and even struggle between belief and unbelief. Taylor wants - by means of his "generous " hermeneutics (Bellah 2007) - to overcome the closed and unfruitful circle of this debate. He wants to show that there is a (dialectical) connection between the so-called belief and unbelief, and that they are not clearly separated poles.

\section{Authenticity ${ }^{8}$}

The age of authenticity is our age which is why it is the most important age for us. Authenticity is "a child " of Romanticism (Taylor 1992, 25) but it became our mass culture ideal in the $60 \mathrm{~s}$ of $20^{\text {th }}$ Century. The most important are not authority or tradition but rather my own spiritual way. What is crucial is a personal resonance, what a particular belief means to me (Hofmann 2017, 277). Is this a wellness-religion? Not necessarily, because we can distinguish between trivial and non-trivial forms of authenticity. These latter imply contexts that transcend an individual, called horizons by Taylor, which only make a non-trivial (definition of) identity possible. ${ }^{9}$

8 Taylor 1991; 1992; 2007, 473ff; Abbey 2000, 86ff; Hoffmann 2017, 276ff. Taylor 1991 appeared originally in Canada as The Malaise of Modernity and was later reprinted in the USA as The Ethics of Authenticity (1992).

9 A crucial and foundational thinker of authenticity is Kierkegaard. Kierkegaard believed that the transcendent dimension of love is a condition of its authenticity (see Máhrik et al. 2018, 51). Moreover, an authentic existence in general - in all its dimensions - is possible only on the basis of the self's relation to Transcendence. This relation is constitutive for all relationships which form an authentic life. (Králik and Torok 2016, 73; Valčová et al. 2016, 102; Králik 2017, 32) 
What implications, trends, forecasts and «morals « can we draw from the fact that our culture is a culture of authenticity? Authentic religion demands much more of personal praxis, personal reflexion, personal experience; it demands greater capacity for argumentation, greater depth of thinking and sensibility on both sides ("providers" and "consumers" of religion). Without achieving of personal resonance, no effort is fruitful. Personal resonance doesn't exclude a support or accompanying and a wish for them. That the journey is personal doesn't imply that one must travel alone. Churches, religious institutions and communities should adapt to this situation if they want to be influential, important, and foremost in a genuine dialogue with the people of the modern world. According to Taylor, the searching for fullness of life is a basic human impulse. With "fullness " he means experiencing of the whole and the meaning which gives life a centre and direction. Also, belief or religion can be understood here as such searching (280). The fact is that we all search for meaning and direction, both believers and non-believers, and a big number of those who feel around somewhere between. Furthermore, all, different believers and (various) unbelievers on the West share the same past, the same genesis of Western society. They were shaped by the same process. As Taylor says, we are »brothers under the skin « (Taylor 2007, 675; Abbey 2017, 228). ${ }^{10}$ All these commonalities can and should help us in our efforts to cultivate mutual respect, understanding, solidarity and dialogue (Abbey 2017, 230).

\section{Reproaches and "Forecasts"}

Taylor's account has been subjected to several criticisms and reproaches. Some of them are not so serious, but others are more fatal. Let us present and evaluate some of them. The first reproach is that Taylor's account of the Middle Ages is too monolithic, it doesn't pay enough attention to the presence of unbelief in the Middle Ages which is relevant also at the sociological scale (Schantz 2009, 34-35). This critique is important, but I don't think it is fatal. Of course, the elaboration of this aspect of Taylor's narrative could bring important new insights and reconfigure to some degree our view about the role of the Middle Ages in the genesis of the secular age. The second critique claims that Taylor reaffirms the religious views, but he doesn't discern the bad from the good among them (35). But clearly some religious views are more anti-intellectual than others, and some are justifiably criticized by an immanentist like Richard Dawkins. I think that this criticism is unfounded. It is evident from Taylor's works what kind of religion he accepts and prefers and what forms of religion he rejects. If we read the passages about traditionalist or anti-modern Catholic views, about anatheism, and ne-

10 We are also susceptible and subjected to similar deviations: „But it's not an accident that >Christiansı fall into similar deviations to those of ssecular humanistsı. As I have tried to show throughout this book, we both emerge from the same long process of Reform in Latin Christendom. We are brothers under the skin.« (Taylor 2007, 675) 
vertheless his defence of the ideal of authenticity against the hard-conservative criticism (Taylor 1991; 1992), we can discern Taylor's relevant criteria.

The third criticism concerns the thesis that the enchanted world is lost for Westerners/Europeans forever (Schantz 2009, 35-36). The counterexample is Iceland where most people still believe in supernatural creatures, encounters of dead persons etc. The next example in this complex is the New Age movement. Taylor interprets it as a reflexion of the culture of authenticity. But isn't it more right to construe it as people's desire for enchanted world? It is not possible to fully answer to these reproaches without some adequate sociological data. But we can nevertheless estimate the power of these claims in case they are true. Regarding Iceland, we can say that it is a similar type of counter-example like the USA: Iceland as such is just not - or wouldn't just be - a part of the European exception. Regarding the New Age movement, it is well known that there are some pretty much consumerist forms of it. In these forms, the New Age is used just as an instrument for relaxation. There is a parallel to some similar non-religious instrumentalist consumerist approaches to yoga, and the classes of the consumers of yoga and the New Age overlap.

But there are maybe more important second thoughts about Taylor's account. One concerns the European exceptionalism (Casanova 2010, 273) and the difference between the USA and Europe (277-280) and thus the justifiability of speaking about the USA and Europe as one civilization. Can this endanger Taylor's main thesis that both Americans and Europeans live today in a secular age?

There are two relevant differences between Europe and the USA. The first concerns the extension of exclusive humanism as an accepted (default) view. There is a salient difference between the USA and Europe in this regard. According to the sociological surveys $(271 ; 280)$, the overwhelming majority of Americans actually don't take exclusive humanism as their option. Most Americans see themselves as religious, not secular humanists (271). A situation is very different in Europe. I don't think that this fact presents a problem for Taylor's thesis that both, Europe and the USA, are secular societies. The reason is that the defining characteristic of secularity in Taylor's sense is not exclusive humanism, but rather the immanent frame. We should not identify the two, they are different concepts. Exclusive humanism is a view that doesn't recognise any transcendence, it practically excludes it. On the other hand, the immanent frame, or the immanent order, allows exclusive humanism as a real option, it allows, permits closure, but it doesn't demand it (Taylor 2007, 543-544). Theoretically it is possible that all members of society A are exclusive humanists, and all members of society B are for instance Christians (or Muslims, or Jews etc.) but still they all live in the immanent frame, i.e. in a secular society/age if in both societies exclusive humanism is understood as a real possible option. The difference shows that the American secularity/secular age is different from the European, that there are two different "subjects « of the secular age in the USA and Europe, maybe even that we are not the same civilization ... But still all that doesn't mean that we - both Americans and Europeans - don't live in secular societies. Moreover, as Casanova points out (2010, 273-274), we can also 
speak about Japanese and even Chinese secularities, which differ not only from the European, but also from the American secularity. Even if secularity became global there would be many secularities because every secularity is a refashioning, reshaping or reconfiguring of a previous (presecular or (possibly) already secular) society. The specific of Europe is not (any more) secularity as such, but if I may put it so, a specific secularity or particularities of its secularity. One of them is the stadial historical consciousness which is not importantly extended nowhere else except in Europe. This is a result of the European unique history. On these special features of secularities, a specific impact of a secularity depends - or will depend. These findings may cause that some will find Taylor's thesis less attractive because of its lesser explanatory power, yet all this, I repeat, does not falsify it.

But there is also another aspect. It concerns the phenomenon that Taylor calls a nova effect (Taylor 2007, 299-313; Smith 2014, 142). According to Taylor, views and opinions in the secular age take place in the space of strong cross pressures. The result is fragilization of all opinions, beliefs and unbeliefs, and proliferation of many different forms and ways of belief and spirituality. The claim about the nova effect is certainly true for the USA, but hardly for Europe if we consider the empirical sociological surveys (Casanova 2010, 280). What we are witnessing in Europe is only a steady decline of the membership in churches and participation in church life. But there is no corresponding proliferation of alternative religious or spiritual transcendent forms (280). In accordance with this fact is the fact that, as Casanova put it, there is no religion that has not taken roots in the USA (280). In Europe, the situation is quite different, now and in the historical perspective. The newcomers are much more pressed to adapt and assimilate. Recent witness to that is the European hostility to Islam (281).

Non-applicability to Europe demands that nova effect is not essential for the secular age. But if we delete nova effect from the list of essential or central characteristics of secularity this means not only that Taylor's view about nova effect as characteristic of the secular age is not exactly true, but it also represents a further impoverishment of Taylor's notion of secularity and weakening of his (hypo)thesis.

At the end let us present some speculations about the secularity and post-secularity in the future. The first relevant factor in this regard is migrations and the influence of non-Christian religions. Considering the above outlined religious openness and pluralism of the USA we should not expect there some drastic change from the aspect of secularity. On the other hand, we have different history and experience in Europe. If the USA is a melting pot of nations, Europe is a melting pot of immigrant religions. However, such a view is set under the question because of Islam. But for believing Muslims, the immanent frame is surely not a default option. On the other hand, we shouldn't expect that Islam will produce a nova effect in Europe.

Considering the global dimension, we should take into account the appearance of non-Western modernities, besides long-time single case of Japan, for instan- 
ce Chinese and Indian (281). China and India are growing global political, economic, technological, and socio-cultural super-powers. Their modernisation can give rise to post-secular Buddhism, Hinduism, Islam, or Confucianism. Their combining with the phenomenon that Casanova calls global denominationalism (deteritorialisation of religious denominations) (281) could generate something we might call global post-secularity. What is important is that the stadial consciousness is specific and unique for the European modernity and secularism. The appearance of non-Western modernizations which wouldn't include the stadial consciousness would - according to Casanova - cause that for the first time in the history Europeans would be aware of the Christian roots of their secularity and of the post-Christian nature of their secularism (281). This would cause, again according to Casanova, a reshaping and re-evaluation of Christianity in Europe and thus a post-secular age in Europe. Nevertheless, despite his speculations, Casanova warns us that it is still premature to forecast the appearance of post-secularity in Europe. But we may agree with Casanova about the possible double merits of Taylor's account: if the post-secular age really comes (in Europe), it would be fair to say not only that Taylor is one of the most important interprets and explainers of the secular age, but also a herald of the post-secular age $(270 ; 281)$. By pointing to the cracks in the immanentist view, he destabilised it and heralded the coming of a new age. But not only the merits, also the approach and Taylor's mind are twofold (270). The first part is his lucid analysis, hermeneutics and genealogy. By it, he has destabilized the foundations and "certainty" of the immanent view. Thus, he has provided the grounding for the second part, his Romantic side, for his will to believe and "utopian « visions of possible future. In any case his work manifests some features that are characteristic for what Hubert Dreyfus has called a paradigm (Dreyfus 2005, 409-418): it is something around what scholars and wider circles of people gather and about what they discuss. Such works, concepts, questions and complex narratives they contain, provide the ground and material, stuff for debate and arguing. Such widely discussed works are drivers and generators of human intellectual and cultural evolution, and of progress. Despite the alleged (and maybe sometimes justified) criticisms, Taylor is surely one of the most important trail-blazers in the area of thought about religion. His work helps us a lot to understand the condition of religion not only in the past and today, but also gives us directions and guidelines, methodological tools, and ideas to more clearly discern its future perspective.

Taylor's understanding of secularity and the secular age helps us also to understand better the phenomenon of the return of religion. The secular age is an age in which no "views" are firm, neither of believers nor of unbelievers, theists or atheists. They all must live with consciousness that they can be wrong and that their belief or unbelief can be false. Upon such intellectual and experiential background, the questions about belief and religion become very relevant. This is one of the reasons for the return of religion not only to the public and political sphere but also to the theoretical area in the sense of the increasing attention and research of religion and religiously relevant phenomena in humanities and social science. 


\section{References}

Abbey, Ruth. 2000. Charles Taylor. Teddington: Acumen.

- - - 2017. Siblings under the skin: Charles Taylor on religious believers and non-believers in $» A$ Secular Age«. In: Anthony Carrol and Richard Norman, eds. Religion and Atheism: Beyond the Divide, 221-231. London \& New York: Routledge.

Bellah, Robert N. 2007. Secularism of a new kind. https://tif.ssrc.org/2007/10/19/secularism-of-a-new-kind/ (accessed April $1^{\text {st }}, 2019$ ).

Casanova, José. 2010. A Secular Age: Dawn or Twilight? In: Michael Warner, Jonathan VanAntwerpen and Craig Calhoun, eds. Varieties of Secularism in a Secular Age, 271-281. Harvard, MA and London, England: Harvard University Pres.

Dreyfus, Hubert L. 2005. Heidegger's Ontology of Art. In: Hubert L. Dreyfus \& Mark A. Wrathall, eds. A Companion to Heidegger, 407-419. Malden, MA \& Oxford, UK \& Carlton, Victoria, Australia: Blackwell Publishing. https://doi. org/10.1111/b.9781405110921.2004.00026.x

Hoffmann, Veronika. 2017. Anders glauben. Geist und Leben 90, no. 3:272-280.

Kearney, Richard, and Charles Taylor. 2016. Transcendent Humanism in a Secular Age: Dialogue with Charles Taylor. In: Richard Kearney and Jens Zimmermann, eds. Reimagining the Sacred: Richard Kearney Debates God, 76-92. New York: Columbia University Press.

Klun, Branko. 2017. Transcendenca, samo-transcendenca in časovnost: fenomenološki razmisleki [Transcendence, Self-Transcendence, and Temporality: Some Phenomenological Reflexions]. Bogoslovni vestnik 77, no. 3/4:503-516.

Králik, Roman, and L'uboš Torok. 2016. Concept of Relationship God-Man in Kierkegaard's Writing »What we learn from the lilies in the field and from the birds in the air«. European Journal of Science and Theology 12, no. 2:65-74.

Králik, Roman. 2017. Søren Kierkegaard's Influence on the Thinking of Karol Nandrásky. European Journal of Science and Theology 13, no. 1:25-34.

Máhrik, Tibor, Martina Pavliková and Jerry Rooot. 2018. Importance of the Incarnation in the Works of C. S. Lewis and S. Kierkegaard. European Journal of Science and Theology 14, no. 2:43-53.
Petkovšek, Robert. 2017. Vloga razuma v samorazumevanju svetopisemskega monoteizma po Janu Assmannu [The Role of Reason in Self-Understanding of Biblical Monotheism ac-cording to Jan Assmann]. Bogoslovni vestnik 77, 3/4:615-636.

Shantz, Douglas H. 2009. The Place of Religion in a Secular Age: Charles Taylor's Explanation of the Rise and Significance of Secularism in the West. https://www.researchgate.net/publication/267998948_The_Place_of_Religion_in_a_ Secular_Age_Charles_Taylor's_Explanation_ of_the_Rise_and_Significance_of_Secularism_in_the_West (accessed April $1^{\text {st }}$, 2019).

Smith, James K. A. 2014. How (Not) to Be Secular: Reading Charles Taylor. Kindle edition.

Strahovnik, Vojko. 2017. Religija, javni prostor in zavzetost v dialogu [Religion, Public Space and Commitment in Dialogue]. Bogoslovni vestnik 77, 2:269-278.

Taylor, Charles. 1989. Sources of the Self: The Making of the Modern Identity. Cambridge, MA \& London, England: Cambridge University Press.

- - - 1990. Religion in a Free Society. In: James Davison Hunter and Os Guiness, eds. Articles of Faith, Articles of Peace: The American Liberty Clauses and the American Public Philosophy, 93-113. Washington, D.C.: The Brooking Institutions.

- - - 1991 The Malaise of Modernity. Concord: Ontario.

- - . 1992. The Ethics of Authenticity. Cambridge, MA \& London, England: Harvard University Press.

- - . 2007. A Secular Age. Cambridge, MA \& London, England: The Belknap of Harvard University Press.

Valčová, Katarina, Martina Pavlíková and Marie Roublová. 2016. Religious Existentialism as a Countermeasure to Moralistic Therapeutic Deism. Communications 18, no. 3:98-104.

Žalec, Bojan. 2016. Origins of nihilism and instrumentalism and the ways to overcome them: the importance of backgrounds. In: Janez Juhant and Bojan Žalec, eds. Which Religion, What Ideology?: The (Religious) Potentials for Peace and Violence, 49-58, 195. Wien: Lit. 